\title{
PENERAPAN MODEL DISCOVERY LEARNING DALAM MENINGKATKAN KUALITAS PEMBELAJARAN DAN HASIL BELAJAR MATEMATIKA PEMINATAN MENGENAI RUMUS JUMLAH DAN SELISIH SINUS DAN KOSINUS DUA SUDUT PADA SISWA KELAS XI IPA 1 SMA NEGERI 1 CISAAT
}

\author{
NIA LUCIANA \\ SMA Negeri 1 Cisaat, Sukabumi, Jawa Barat \\ e-mail : nialuciana@gmail.com
}

\begin{abstract}
ABSTRAK
Kegiatan ini fokus pada penerapan model discovery learning dalam proses pembelajaran trigonometri rumus jumlah dan selisih sinus dan kosinus dua sudut di kelas XI IPA 1 SMA Negeri 1 Cisaat. Tujuan penelitian ini adalah untuk mendokumentasikan praktik terbaik dari pelaksanaan kegiatan pembelajaran yang dilakukan guru dalam rangka meningkatkan kualitas pembelajaran dan hasil belajar siswa. Metode yang digunakan dalam penelitian ini adalah penelitian kualitatif dengan pendekatan Best Practices. Dalam pelaksanaan Best Practices, digunakan strategi pemecahan masalah dengan konseptualisasi penyelesaian masalah dengan 3 tahap yaitu perencanaan, pelaksanaan dan evaluasi. Model pembelajaran yang digunakan adalah discovery learning untuk menemukan dan menurunkan rumus trigonometri jumlah dan selisih dua sudut yang diarahkan dalam sebuah LKPD. Peningkatan kemampuan pengetahuan dan keterampilan siswa dalam penerapan model discovery learning ini ditunjukkan dari perolehan nilai hasil belajar siswa yang mengalami peningkatan dari nilai pre test yang awalnya hanya $50 \%$ siswa mencapai KKM 78 meningkat menjadi 100\% siswa yang mencapai KKM 78. Selain meningkatkan hasil belajar matematika siswa, penerapan model discovery learning di kelas XI IPA 1 SMA Negeri 1 Cisaat membuat proses pembelajaran yang terjadi cukup menyenangkan dan memberi kesan baik terhadap matematika.
\end{abstract}

Kata Kunci: discovery learning, hasil belajar matematika, rumus trigonometri

\section{PENDAHULUAN}

Selama hampir empat belas tahun sudah saya mengabdikan diri di SMA dalam berbagi ilmu pada mata pelajaran Matematika. Ragam rupa dan karakter siswa pernah saya temui, baik di program IPA maupun IPS. Ketika saya memasuki ruang kelas yang berisikan 36 orang siswa di kelas XI IPA SMA Negeri 1 Cisaat, maka yang ada di benak saya adalah siswa siswa tersebut memiliki kemampuan kognitif yang cukup baik, kecerdasan yang rata rata baik sehingga akan berdampak pada proses pembelajaran yang cukup kondusif. Namun, pada kenyataannya, terdapat keberagaman kemampuan kognitif di kelas XI IPA sekali pun, sehingga perlu sekali sebuah metode pembelajaran yang inovatif dan menyenangkan agar kualitas pembelajaran dan hasil belajar dapat meningkat.

Peraturan Menteri Pendidikan dan Kebudayaan Republik Indonesia Nomor 22 Tahun 2016 tentang Standar Proses Pendidikan Dasar dan Menengah, menuntut guru mampu melaksanakan pembelajaran yang interaktif, inspiratif, menyenangkan, menantang, dan memotivasi siswa untuk aktif dalampembelajaran. Oleh karena itu, guru harus menerapkan pendekatan ilmiah dalam proses pembelajarannya, sehingga siswa dapat secara aktif mengembangkan sikap, pengetahuan dan keterampilannya.

Terlebih lagi, saat diberlakukannya Implementasi Kurikulum 2013, merekomendasikan sebuah pendekatan pembelajaran saintifik, dengan model Discovery Learning, Problem Based Learning atau Project Based Learning. Hal ini memberi motivasi tersendiri untuk saya, agar mampu mengimplementasikan pembelajaran dengan pendekatan saintifik. Tantangan yang cukup berat di awal implementasinya, namun saya yakin bahwa segala sesuatu lebih baik dilaksanakan sesuai kemampuan dibanding jika tidak dilakukan sama sekali. 
Salah satu kompetensi dasar mata pelajaran Matematika SMA yang harus dikuasai siswa adalah trigonometri. Ada banyak kegunaan trigonometri dalam kehidupan sehari-hari, di antaranya teknik triangulasi yang digunakan dalam astronomi untuk menghitung jarak ke bintang-bintang terdekat, dalam geografi untuk menghitung antara titik tertentu, dan sistem navigasi satelit. Bidang lain yang menggunakan trigonometri termasuk astronomi, teori musik, akustik, optik, analisis pasar finansial, elektronik, teori probabilitas, statistika, meteorologi dan banyak bidang lainnya (Wikipedia, Trigonometri : 2021).

Rumus trigonometri jumlah dan selisih sinus dan kosinus dua sudut adalah salah satu bagian materi trigonometri yang perlu dikuasai siswa SMA khususnya siswa yang memilih jurusan IPA. Karakteristik materi trigonometri secara umum sama dengan karakteristik matematika. Menurut Soedjadi (2007 : 9) matematika memiliki karakteristik yaitu : memiliki objek kajian yang abstrak, bertumpu pada kesepakatan, berpola pikir deduktif, memiliki simbol yang kosong dari arti, memperhatikan semesta pembicaraan dan konsisten dalam sistemnya. Berdasarkan karakteristik itulah, materi trigonometri rumus jumlah dan selisih sinus dan kosinus dua sudut merupakan materi yang cukup sulit dikuasai oleh siswa SMA kelas XI IPA. Oleh karena itu, perlu disiapkan sebuah desain pembelajaran yang bisa diikuti siswa secara aktif dan memudahkan siswa dalam memahami materi tersebut.

Realita yang dihadapi saat ini adalah siswa masih belum mampu menguasai kompetensi trigonometri yang diharapkan. Hal ini terbukti dari hasil belajar matematika siswa yang masih rendah. Berdasarkan hasil pre test terhadap kompetensi trigonometri : rumus jumlah dan selisih sinus dan kosinus dua sudut, dengan KKM 78, dari 36 siswa hanya 18 siswa (50\%) yang telah tuntas dan 18 siswa (50\%) belum tuntas pada aspek pengetahuan maupun keterampilan.

Untuk mengatasi permasalahan di atas, maka salah satu solusi yang dapat dilakukan adalah dengan menerapkan model pembelajaran discovery learning. Melaluidiscovery siswa dapat menggunakan proses mentalnya untuk menemukan beberapa konsep dan prinsip. Discovery atau penemuan dilakukan melalui observasi, klasifikasi, pengukuran, prediksi, penentuan, dan inferensi (kesimpulan). Penggunaan discovery learning, ingin mengubah kondisi belajar yang pasif menjadi aktif dan kreatif. Mengubah pembelajaran yang teacher oriented ke student oriented. Mengubah modus ekspositori, saat siswa hanya menerima informasi secara keseluruhan dari guru ke modus Discovery, saat siswa diarahkan mampu menemukan informasi sendiri (Kemendikbud, 2014 : 89)

Dalam kaitannya dengan pendidikan, Hamalik (dalam Takdir, 2012:29) menyatakan bahwa discovery adalah proses pembelajaran yang menitikberatkan pada mental intelektual pada anak didik dalam memecahkan berbagai persoalan yang dihadapi, sehingga menemukan suatu konsep yang dapat diterapkan di lapangan. Selain itu, Mulyasa (dalam Takdir, 2012:32) menyatakan bahwa discovery merupakan strategi pembelajaran yang menekankan pengalaman langsung dilapangan, tanpa harus selalu bergantung pada teori-teori pembelajaran yang ada dalam pedoman buku pelajaran. Sebagai strategi belajar, discovery learning, mempunyai prinsip yang sama dengan inkuiri dan problem solving. Perbedaannya, pada discovery, masalah yang dihadapkan kepada siswa semacam masalah yang direkayasa oleh guru. Atas dasar latar belakang itulah, dalam rangka memperbaiki kualitas pembelajaran dan meningkatkan hasil belajar Matematika Peminatan, penulis ingin berbagi sedikit pengalaman dalam penerapan model discovery learning untuk meningkatkan kualitas pembelajaran dan hasil belajar Matematika Peminatan mengenai rumus jumlah dan selisih sinus dan kosinus dua sudut, pada siswa kelas XI IPA 1 SMA Negeri 1 Cisaat.

\section{METODE PENELITIAN}

Metode yang digunakan dalam penelitian ini adalah penelitian kualitatif dengan pendekatan Best Practices. Dalam pelaksanaan Best Practices, digunakan strategi pemecahan masalah dengan konseptualisasi penyelesaian masalah dengan 3 tahap yaitu perencanaan, pelaksanaan dan evaluasi. Best Practices ini dilaksanakan pada semester 1 tahun pelajaran 2019/2020, yaitu sekitar bulan Agustus sampai dengan September 2019 di kelas XI IPA 1 SMA Negeri 1 Cisaat. 
Langkah pelaksanaan Best Practices terdiri dari Stimulation (stimulai/pemberian rangsangan), Problem statement (pernyataan/identifikasi masalah), Data collection (pengumpulan data), Data processing (pengolahan data), Verification (pembuktian), dan Generalization (menarik kesimpulan/generalisasi). Kemudian dilanjutkan tahap Evaluasi proses pembelajaran dan hasil pembelajaran Matematika.

\section{HASIL DAN PEMBAHASAN PENELITIAN}

Setelah selesai pembelajaran, guru memeriksa hasil kerja siswa dan melakukan analisis. Berdasarkan hasil analisis dapat diketahui hasil evaluasi siswa sebagai berikut :

Tabel 1 Hasil Belajar Matematika Siswa

\begin{tabular}{|c|c|c|c|c|c|}
\hline No. & Nama Siswa & $\begin{array}{c}\text { Nilai } \\
\text { Pengetahuan }\end{array}$ & Kriteria & $\begin{array}{c}\text { Nilai } \\
\text { Keterampilan }\end{array}$ & Kriteria \\
\hline 1 & SISWA 1 & 79 & Mencapai KKM & 78 & Terampil \\
\hline 2 & SISWA 2 & 84 & Mencapai KKM & 84 & Terampil \\
\hline 3 & SISWA 3 & 82 & Mencapai KKM & 82 & Terampil \\
\hline 4 & SISWA 4 & 82 & Mencapai KKM & 82 & Terampil \\
\hline 5 & SISWA 5 & 86 & Mencapai KKM & 86 & Terampil \\
\hline 6 & SISWA 6 & 81 & Mencapai KKM & 81 & Terampil \\
\hline 7 & SISWA 7 & 86 & Mencapai KKM & 86 & Terampil \\
\hline 8 & SISWA 8 & 90 & Mencapai KKM & 90 & Terampil \\
\hline 9 & SISWA 9 & 81 & Mencapai KKM & 81 & Terampil \\
\hline 10 & SISWA 10 & 82 & Mencapai KKM & 82 & Terampil \\
\hline 11 & SISWA 11 & 82 & Mencapai KKM & 82 & Terampil \\
\hline 12 & SISWA 12 & 84 & Mencapai KKM & 84 & Terampil \\
\hline 13 & SISWA 13 & 80 & Mencapai KKM & 80 & Terampil \\
\hline 14 & SISWA 14 & 84 & Mencapai KKM & 84 & Terampil \\
\hline 15 & SISWA 15 & 81 & Mencapai KKM & 81 & Terampil \\
\hline 16 & SISWA 16 & 82 & Mencapai KKM & 82 & Terampil \\
\hline 17 & SISWA 17 & 93 & Mencapai KKM & 93 & Terampil \\
\hline 18 & SISWA 18 & 89 & Mencapai KKM & 89 & Terampil \\
\hline 19 & SISWA 19 & 80 & Mencapai KKM & 78 & Terampil \\
\hline 20 & SISWA 20 & 83 & Mencapai KKM & 83 & Terampil \\
\hline 21 & SISWA 21 & 81 & Mencapai KKM & 81 & Terampil \\
\hline 22 & SISWA 22 & 82 & Mencapai KKM & 82 & Terampil \\
\hline 23 & SISWA 23 & 82 & Mencapai KKM & 82 & Terampil \\
\hline 24 & SISWA 24 & 81 & Mencapai KKM & 81 & Terampil \\
\hline 25 & SISWA 25 & 83 & Mencapai KKM & 83 & Terampil \\
\hline 26 & SISWA 26 & 82 & Mencapai KKM & 82 & Terampil \\
\hline 27 & SISWA 27 & 82 & Mencapai KKM & 78 & Terampil \\
\hline 28 & SISWA 28 & 83 & Mencapai KKM & 83 & Terampil \\
\hline 29 & SISWA 29 & 80 & Mencapai KKM & 80 & Terampil \\
\hline 30 & SISWA 30 & 88 & Mencapai KKM & 88 & Terampil \\
\hline 31 & SISWA 31 & 81 & Mencapai KKM & 81 & Terampil \\
\hline 32 & SISWA 32 & 81 & Mencapai KKM & 81 & Terampil \\
\hline 33 & SISWA 33 & 87 & Mencapai KKM & 87 & Terampil \\
\hline 34 & SISWA 34 & 83 & Mencapai KKM & 83 & Terampil \\
\hline 35 & SISWA 35 & 81 & Mencapai KKM & 81 & Terampil \\
\hline 36 & SISWA 36 & 82 & Mencapai KKM & 82 & Terampil \\
\hline
\end{tabular}


Berdasarkan tabel di atas, maka dapat dihitung ketuntasan klasikal siswa untuk kompetensi dasar pengetahuan dan keterampilan menggunakan rumus berikut :

$\mathrm{KK}=\frac{\text { jumlah siswa yang mencapai } K K M}{\text { jumlah seluruh siswa }} \times 100 \%=\frac{36}{36} \times 100 \%=100 \%$

Sehingga diperoleh ketuntasan klasikal siswa sebesar $100 \%$, untuk kompetensi dasar pengetahuan dan keterampilan dalam kompetensi rumus trigonometri jumlah dan selisih sinus dan kosinus dua sudut. Ini berarti seluruh siswa telah tuntas. Ketuntasan klasikal kompetensi dasar pengetahuan dan keterampilan siswa meningkat sebesar 50\%, yaitu dari 50\% pada hasil pre test menjadi $100 \%$ setelah tindakan. Peningkatan sikap dan ketuntasan klasikal pada kompetensi pengetahuan dan keterampilan siswa menunjukkan bahwa penerapan Model Pembelajaran discovery learning sangat efektif dalam meningkatkan hasil belajar Matematika siswa. Hal ini dikarenakan model pembelajaran ini dapat membantu siswa dalam memahami konsep, arti, dan hubungan melalui proses intuitif hingga akhirnya siswa mampu membuat suatu kesimpulan (Ariyana, dkk. 2019).

Hasil yang dicapai dari penerapan model discovery learning pada materi rumus trigonometri jumlah dan selisih sinus dan kosinus dua sudut, tampak di antaranya sebagai berikut : 1) Proses pembelajaran berlangsung cukup kondusif karena semua siswa diarahkan untuk terlibat aktif menemukan dan mengolah informasi yaitu rumus trigonometri jumlah dan selisih sinus dan kosinus dua sudut. 2) Proses pembelajaran mampu berjalan dengan membelajarkan siswa dan menjadikan siswa sebagai subyek pembelajar aktif (student centre) dan guru berperan penuh sebagai fasilitator. 3) Proses pembelajaran mengembangkan rasa ingin tahu, kerja sama, partisipasi aktif, keuletan, pantang menyerah, kedisiplinan, kepercayaan diri dan kemandirian siswa. 4) Proses pembelajaran yang terjadi cukup menyenangkan dan membuat kesan baik terhadap Matematika karena tumbuhnya rasa menyelidiki dan berhasil. 5) Hasil belajar matematika yang diperoleh cukup meningkat dan merata dari semua siswa yaitu mencapai dan melampaui KKM, jika dibandingkan prestasi siswa di kelas lain yang belum menerapkan model discovery learning. 6) Berpusat pada siswa dan guru berperan sama-sama aktif mengeluarkan gagasan-gagasan. Bahkan guru pun bisa bertindak sebagai peneliti dalam situasi diskusi.

Hasil tersebut sejalan dengan beberapa kelebihan mengajar dengan model discovery learning yang dikemukakan Takdir (2012:70) yaitu: 1) Dalam penyampaian bahan discovery, digunakan kegiatan dan pengalaman langsung. Kegiatan dan pengalaman tersebut akan lebih menarik perhatian anak didik dan memungkinkan pembentukan konsep-konsep abstrak yang mempunyai makna 2) Discovery Strategy lebih realistis dan mempunyai makna. Sebab, para anak didik dapat bekerja langsung dengan contoh-contoh nyata 3) Discovery Strategy merupakan suatu model pemecahan masalah. Para anak didik langsung menerapkan prinsip dan langkah awal dalam pemecahan masalah. Melalui strategi ini mereka mempunyai peluang untuk belajar lebih intens dalam memecahkan masalah sehingga dapat berguna dalam menghadapi kehidupan dikemudian hari 4) Dengan sejumlah transfer secara langsung, maka kegiatan discovery strategy akan lebih mudah diserap oleh anak didik dalam memahami kondisi tertentu yang berkenaan dengan aktivitas pembelajaran 5) Discovery Strategy banyak memberikan kesempatan bagi para peserta didik untuk terlibat langsung dalam kegiatan belajar.

Beberapa kelebihan model discovery learning juga diungkapkan oleh Suherman, dkk (2001: 179) sebagai berikut: 1. Siswa aktif dalam kegiatan belajar, sebab ia berpikir dan menggunakan kemampuan untuk menemukan hasil akhir; 2. Siswa memahami benar bahan pelajaran, sebab mengalami sendiri proses menemukannya. Sesuatu yang diperoleh dengan cara ini lebih lama diingat; 3. Menemukan sendiri menimbulkan rasa puas. Kepuasan batin ini mendorong ingin melakukan penemuan lagi sehingga minat belajarnya meningkat; 4. Siswa yang memperoleh pengetahuan dengan metode penemuan akan lebih mampu mentransfer pengetahuannya ke berbagai konteks.

Hasil penerapan model discovery learning dalam pembelajaran matematika tersebut juga sesuai dengan penelitian yang dilakukan oleh Ardika (2019:17) yang mengemukakan 
bahwa penerapan model discovery learning dalam pembelajaran matematika sangat efektif meningkatkan hasil belajar matematika siswa. Selain itu, hasil ini pun sejalan dengan penelitian yang dilakukan oleh Hadi (2019:31) mengemukakan bahwa penerapan model discovery learning dalam pembelajaran matematika membuat pembelajaran menjadi lebih hidup dan peserta didik lebih aktif dalam mengikuti pembelajaran serta mampu meningkatkan kemampuan peserta didik dalam berfikir kritis dan menemukan pemecahan masalah.

Adapun kendala yang dihadapi dalam penerapan model discovery learning pada materi rumus trigonometri jumlah dan selisih sinus dan kosinus dua sudut adalah :

1. Metode ini menimbulkan asumsi adanya kesiapan belajar. Jadi, bagi siswa yang belum siap belajar secara mental akan merasa jenuh dalam mengikuti pembelajaran, siswa seperti ini akan membuat aktivitas kelompok menjadi terhambat. (Kemdikbud, 2014 : 91).

2. Membutuhkan waktu yang cukup lama untuk membantu siswa dalam memahami teori dan pemecahan masalah lainnya.

3. Waktu yang dibutuhkan untuk melaksanakan penerapan model discovery learning pada materi ini, cukup lama jika dibandingkan dengan model penemuan langsung karena perlu kerja sama kelompok yang baik jika ingin penemuannya berjalan lancar.

4. Tidak menyediakan kesempatan berfikir yang akan ditemukan oleh siswa karena telah dipilih dan direkayasa oleh guru.(Kemdikbud, 2014 : 92).

5. Cukup membatasi siswa dalam menentukan hipotesis, namun di sisi lain, siswa bekerja lebih efektif dan efisien.

6. Beberapa siswa tampak belum faham dalam penerapan model discovery learning sehingga sedikit lebih lambat dalam memulai aktivitas sesuai petunjuk yang telah disusun dalam Lembar Kerja Peserta Didik.

Keadaan tersebut sesuai dengan beberapa kelemahan penerapan model discovery learning yang dikemukakan Takdir (2012:70), yaitu: a) Guru merasa gagal mendeteksi masalah dan adanya kesalahpahaman antara guru dengan siswa. b) Menyita pekerjaan guru. c) Tidak semua siswa mampu melakukan penemuan. d) Tidak berlaku untuk semua topik. Beberapa faktor yang mendukung keberhasilan penerapan model discovery learning pada materi rumus trigonometri jumlah dan selisih sinus dan kosinus dua sudut adalah sebagai berikut :

1. Dukungan siswa yang kooperatif dengan desain pembelajaran yang telah disusun oleh guru. Dukungan fasilitas pembelajaran yang ada di sekolah, berupa buku penunjang, internet dan media presentasi.

2. Kajian teori yang sangat lengkap dari berbagai sumber mengenai penerapan discovery learning.

3. Tulisan-tulisan ilmiah berupa penulisan best practice mengenai penerapan model discovery learning dalam pembelajaran Matematika dari guru-guru sebelumnya.

4. Guru dan siswa diberikan nikmat waktu, ilmu dan kesehatan yang sangat berharga oleh Allah SWT sehingga seluruh kegiatan berlangsung lancar.

Setelah melaksanakan penerapan model discovery learning pada materi rumus trigonometri jumlah dan selisih sinus dan kosinus dua sudut, saya bersama rekan sejawat berusaha mengembangkan terus model desain pembelajaran yang efektif, efisien dan menyenangkan bagi siswa, sesuai kajian pustaka dan penelitian yang telah ada sebelumnya, dengan tujuan mengembangkan kemampuan siswa dalam pembelajaran dan meningkatkan hasil belajar matematika siswa melalui pembelajaran yang menyenangkan.

Alternatif model lain yang bisa diterapkan dalam pembelajaran matematika adalah Project Based Learning dan Problem Based Learning yang bisa dikolaborasikan dengan berbagai strategi pembelajaran lainnya.

\section{KESIMPULAN}

Berdasarkan hasil serta pembahasan dalam kegiatan best practice ini dapat disimpulkan bahwa sebelum dilakukan tindakan, pengetahuan, dan keterampilan siswa dalam menerapkan 
rumus trigonometri jumlah dan selisih sinus dan kosinus dua sudut masih rendah yaitu $50 \%$. Kompetensi dasar yang dituntut adalah siswa mampu menurunkan rumus-rumus tersebut sehingga perlu sebuah pembelajaran yang melibatkan siswa secara aktif dalam menurunkan rumus trigonometri tersebut. Model discovery learning cukup sesuai diterapkan dalam pembelajaran matematika untuk menurunkan dan menemukan rumus jumlah dan selisih sinud dan kosinus dua sudut karena mengarahkan siswa menemukan sendiri rumus-rumus yang harus dikuasai. Dengan demikian, siswa tidak hanya menghapal rumus tanpa makna, namun, siswa memahami dari mana asal rumus tersebut, serta memahami bagaimana cara menurunkan rumus-rumus tersebut dari informasi awal yang sudah mereka peroleh. Terjadilah pembelajaran bermakna untuk siswa yang diharapkan hasilnya pun bisa lebih difahami dan mudah diaplikasikan dalam penyelesaian masalah Matematika. Hal ini tentu saja berpengaruh dalam peningkatan hasil belajar Matematika siswa, terutama pada materi Rumus Jumlah dan Selisih Sinus dan Kosinus Dua Sudut. Kualitas pembelajaran matematika meningkat dengan menerapkan model discovery learning serta adanya perubahan positif pada aspek situasi belajar, perhatian, keaktifan, serta proses belajar mengajar menjadikan pembelajaran matematika khusunya trigonometri lebih menarik, menyenangkan, dan tidak membosankan. Pembelajaran dengan discovery learning dapat meningkatkan hasil belajar matematika siswa. Hal ini terlihat dari peningkatan nilai pengetahuan dan keterampilan siswa yang awalnya hanya $50 \%$ siswa mencapai KKM 78 menjadi 100\% siswa mencapai KKM 78. Dari hasil best practice di atas terlihat bahwa penerapan model discovery learning dalam materi rumus jumlah dan selisih sinus dan kosinus dua sudut dapat meningkatkan kualitas pembelajaran dan hasil belajar siswa XI IPA 1 di SMA Negeri 1 Cisaat.

\section{DAFTAR PUSTAKA}

Ardika, I Wayan. (2019). Penerapan Model Pembelajaran Discovery Learning Berbantuan Keping Muatan Untuk Meningkatkan Hasil Belajar Matematika Siswa Kelas VI Semester I SDN 6 Yehembang. Laporan Best Practice (diunduh). SDN 6 Yehembang.

Ariyana, Yoki, dkk. (2019). Buku Pegangan Pembelajaran Berorientasi pada Keterampilan Berpikir Tingkat Tinggi. Jakarta: Dirjen GTK, Kemdikbud.

Hadi, Daria Affani. (2019). Implementasi Model Pembelajaran Discovery Learning Berorientasi HOTS Pada Mata Pelajaran Matematika di SMK Negeri 7 Mataram. SUPERMAT Jurnal Pendidikan Matematika. Volume 4, No. 1, April 2020.

Kementrian Pendidikan Kebudayaan. (2014). Materi Pelatihan Guru Implementasi Kurikulum 2013 Mata Pelajaran Matematika SMA/SMK. Jakarta : Badan Pengembangan Sumber Daya Manusia Pendidikan dan Kebudayaan dan Penjaminan Mutu Pendidikan.

Peraturan Menteri Pendidikan dan Kebudayaan Republik Indonesia Nomor 22 Tahun 2016 tentang Standar Proses Pendidikan Dasar dan Menengah.

Soedjadi, R. (2007). Kiat Pendidikan Matematika di Indonesia. Jakarta : Direktorat Jendral Tinggi Departemen Pendidikan Nasional.

Syah. (2004). Psikologi Pendidikan dengan Pendekatan Baru. Bandung : PT Remaja Rosdakarya.

Takdir. (2012). Pembelajaran Discovery Strategy dan Mental Vocational Skill. Jogjakarta : Diva Press.

Wikipedia. (2021). Trigonometri. (Online). https://id.wikipedia.org/wiki/Trigonometri. Diakses : 23 April 2021. 